\title{
Ectopic pancreas mimicking gastrointestinal stromal tumor in the stomach fundus
}

Ectopic or heterotopic pancreas refers to healthy pancreatic tissue that lacks anatomical, vascular or neural communication with the normal pancreas. However, heterotopic pancreas is seldom considered as a diagnostic hypothesis when symptomatic or when located outside of the gastric antral wall [1]. This case report describes the clinical and paraclinical features of pancreatic heterotopia in the gastric fundus in a previously healthy 25-year-old woman.

Initially, a gastrointestinal stromal tumor (GIST) was highly suspected because of its endoscopic (location and shape; - Video 1), endoscopic ultrasound (emerging layer; $>$ Fig. 1, > Fig. 2), and computed tomography characteristics; however, the histopathological evaluation revealed pancreatic heterotopia ( Fig.3). Although the patient was asymptomatic, we opted for surgical treatment because of the large size of the lesion, the atypical location in a highly vascularized part of the stomach, and the patient's young age.

On postsurgical follow-up, only a small granuloma was found on the suture site, even though the surgery was not curative ( $R 1$ with remaining pancreatic tissue on one margin of the resection specimen) ( $\mathbf{F i g}$.4). We emphasize the unusual location of the pancreatic heterotopia (gastric fundus - despite up to $95 \%$ of cases being found in the antral location), and the layer from which the tissue developed (muscularis propria - which is seen in only $17 \%$ of cases) [2]. Moreover, we emphasize the difficulty in making an accurate diagnosis, which can only be obtained after surgery, and the need for regular postoperative follow-up to assess for remaining pancreatic rests, as some studies have shown up to $12.7 \%$ malignant transformation in pancreatic rests [3].

Despite the fact that ectopic pancreas is a rare condition, one must consider the differential diagnosis of extramucosal gastric lesions. Even though endoscopic

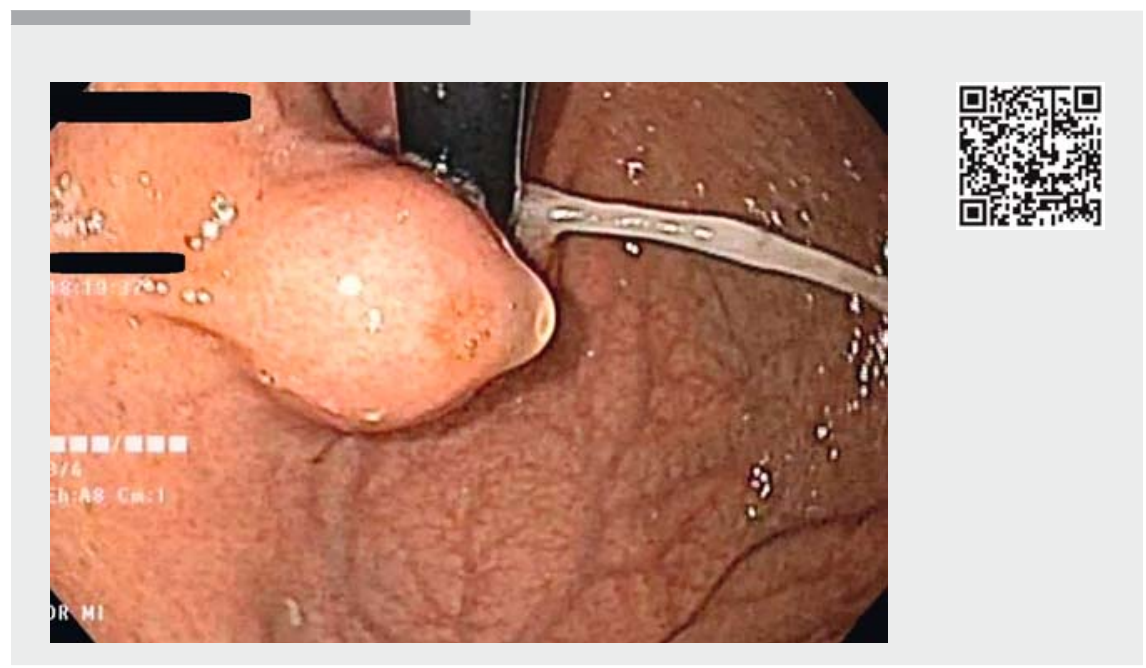

Video 1 Endoscopic appearence of a submucosal lesion, with central ulceration, in the gastric fundus. Narrow-band imagining revealed regular microvascular and surface patterns, except for the central zone, which had irregular surface and vascular patterns.

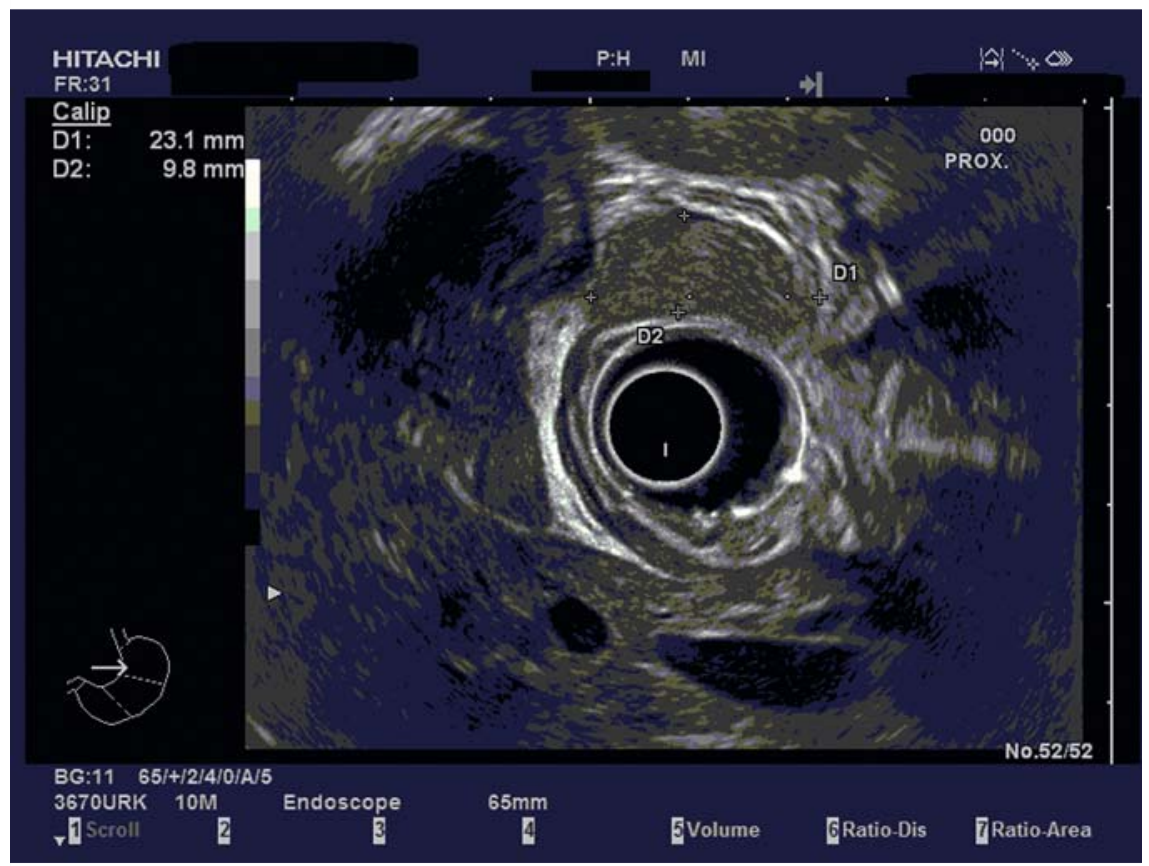

- Fig. 1 A $23.1 \times 9.8 \mathrm{~mm}$ oval lesion, homogeneous, located within the 4th hypoechoic layer, well delineated, and with possible extension of the lesion through the 5 th hyperechoic outer layer. 


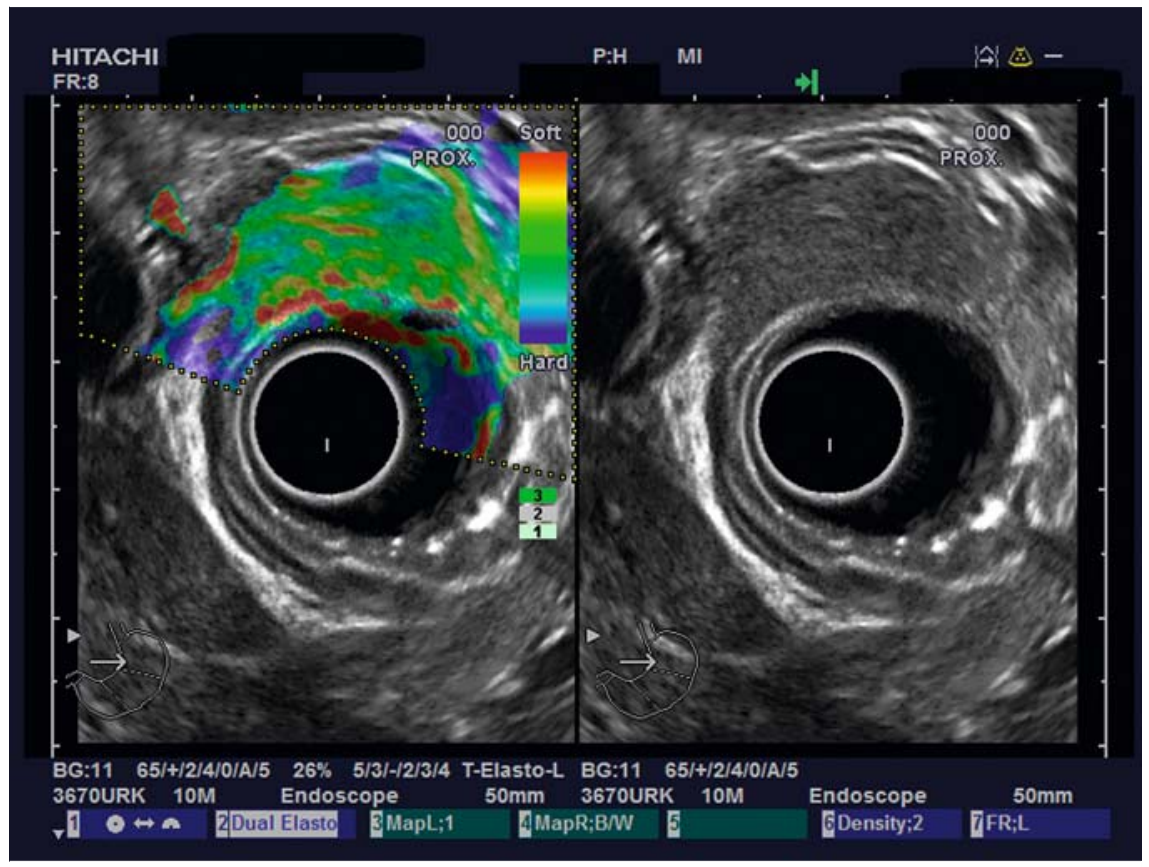

Fig. 2 Soft aspect of the lesion shown by elastography scanning.

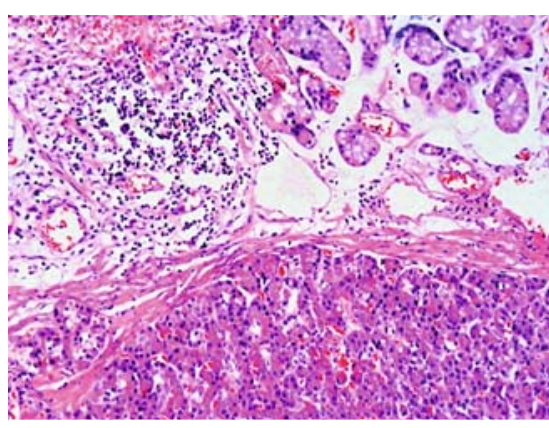

- Fig. 3 Histopathological evaluation revealed gastric mucosa with fundic glands and pancreatic tissue beneath the muscularis mucosae fibers (Hematoxylin and eosin, $\times 200)$.

ultrasonography has become an essential tool in diagnosing submucosal masses, sometimes it cannot make a clear distinction between pancreatic rests and GISTs. Preoperative and even intraoperative diagnosis is rare, and surgical excision by minimally invasive approach remains the recommended treatment in symptomatic cases $[1,4]$.

Endoscopy_UCTN_Code_CCL_1AB_2AD_3AB

Competing interests

None
Corresponding author

\section{Cătălina Diaconu, MD}

Department of Gastroenterology, Floreasca Clinical Emergency Hospital, Floreasca Street 8, PC 014461 Bucharest, Romania Fax: +40-21-5992300

catalinadiaconu89@gmail.com

References

[1] Podolsky D, Camilleri M, Kalloo A, Shanahan F. Yamada's textbook of gastroenterology. 6th edn. Sussex: Wiley Blackwell; 2016: $126,1152-1153$

[2] Târcoveanu E, Vasilescu A, Vlad N et al. Cystic pancreatic heterotopia - rare case of antro-pyloric stenosis in adults. Heterotopie pancreatică chistică - cauză rară de stenoză antropilorică la adulți. Rom J Surg 2011; 7: $424-430$

[3] Nakao T, Yanoh K, Itoh A. Aberrant pancreas in Japan. Review of the literature and report of 12 surgical cases. Med J Osaka Univ 1980; 30: $57-63$

[4] Guimarães M, Rodrigues P, Gonçalves G et al. Heterotopic pancreas in excluded stomach diagnosed after gastric bypass surgery. BMC Surg 2013; 13: 56

\section{Bibliography}

DOI https://doi.org/10.1055/a-0605-2996

Published online: 9.5.2018

Endoscopy 2018; 50: E186-E187

(c) Georg Thieme Verlag KG

Stuttgart · New York

- Fig.4 Post-resection endoscopic appearance, with mucosal proliferation near the suture site with surgical thread in place, highly suggestive of suture granuloma.

The authors

Cătălina Diaconu' ${ }^{1}$, Mihai Ciocîrlan ${ }^{2}$, Mariana Jinga ${ }^{3}$, Raluca Simona Costache ${ }^{3}$, Gabriel Constantinescu ${ }^{1}$, Mădălina llie ${ }^{1}$, Mircea

Diculescu 4

1 Department of Gastroenterology, Floreasca Clinical Emergency Hospital, Bucharest, Romania

2 Department of Gastroenterology, Agripa Ionescu Hospital, Bucharest, Romania

3 Department of Gastroenterology, Central Military Emergency University Hospital, Bucharest, Romania

4 Department of Gastroenterology, Fundeni Clinical Institute, Bucharest, Romania
ENDOSCOPY E-VIDEOS

https://eref.thieme.de/e-videos

口回 Endoscopy E-Videos is a free 自: on interesting cases and new techniques in gastroenterological endoscopy. All papers include a high quality video and all contributions are freely accessible online.

This section has its own submission website at https://mc.manuscriptcentral.com/e-videos Fection, reporting 